Мирошниченко Ю. М., кандидат юридичних наук, голова Іллічівського районного суду м. Маріуполя Донецької області

\title{
ПРО ДЕТЕРМІНАНТИ ТАКТИКИ СУДУ В КРИМІНАЛЬНОМУ ПРОВАДЖЕННІ
}

\begin{abstract}
Анотація. На підставі системно-філософського аналізу відносин суду з іншими суб'єктами кримінального провадження обгрунтовується необхідність розробки тактичних засобів оптимізації судової діяльності. Підкреслюється, що термін «тактика», запозичений з галузі військової науки, набув у криміналістиці іншого лексичного значення. Зроблено висновок про те, що визначальним у формуванні поняття «тактика» $\epsilon$ сукупність засобів і прийомів досягнення намічених цілей. Через свою всезагальність ця ознака стає домінуючою, відсуваючи на другий план конфліктність, наявність якої наразі не має принципово детермінуючого значення.
\end{abstract}

Ключові слова: кримінальне провадження, процесуальний конфлікт, тактика суду.

Постановка проблеми. Криміналістика виникла як наука про методи розслідування злочинів. Тому спочатку сферою застосування іiі рекомендацій була тільки галузь досудового розслідування. Однак у міру розвитку криміналістичної науки ставало більш ясним, що ії рекомендації можуть з успіхом бути використані й у процесі судового розгляду у разі проведення тих чи інших дій $з$ дослідження й оцінки наявних і збирання нових доказів. Дослідження можливостей і меж застосування даних криміналістики судом у низці випадків виявило необхідність таких криміналістичних рекомендацій, які призначалися $\sigma$ саме для суду, враховували специфіку судового провадження i його відмінності від досудового розслідування [1, с. 38].

Проте й у сучасній навчальній літературі, розрізняючи в структурі криміналістичної тактики слідчу тактику і тактику судову, автори зосереджуються виключно на висвітленні питань тактики досудового розслідування [2], забуваючи про тактику судового провадження, специфіку судових ситуацій, особливості судового допиту, огляду, інших процесуальних дій слідчого характеру. Поза увагою залишається також надзвичайно важливий для ефективного судочинства напрям криміналістичної тактики - організація і планування судового розгляду.

Аналіз останніх досліджень. На різних етапах розвитку криміналістики до питань використання іiі напрацювань судом так чи інакше зверталися Л.Ю. Ароцкер, І.Є. Биховський, В.М. Бозров, А.І. Вінберг, Г.А. Воробйов, М.М. Видря, В.П. Колмаков, Ю.В. Кореневський, Н.Н. Медведсв, І.Ф. Пантелєєв, С.П. Сухов, В.Г. Тихиня, Н.І. Хлюпін, А.Л. Ципкін. Протягом останнього десятиліття розробкам криміналістичних рекомендацій для потреб судової практики присвячені дисертаційні дослідження М.Й. Вільгушинського, І.І. Когутича, О.Ю. Корчагіна, С.В. Кобилинської, І.В. Румянцевої, 0.0. Сичової. Незважаючи на це, ступінь вивченості та наукової опрацьованості проблем тактико-криміналістичного забезпечення судового провадження ще не відповідає актуальності зазначеної тематики. Певним чином такому стану справ сприяє негативне ставлення окремих науковців до використання судом тактичних прийомів і методів.

Найпалкішим противником розробки тактики суду в кримінальному процесі був професор О.Я. Баєв. Тенденції розвитку пострадянського процесуального права у напрямі розширення змагальних засад кримінального судочинства та одночасного згортання доказової активності суду остаточно зміцнили його в думці про те, що законодавець закрив питання про суд як суб'єкт криміналістики, однозначно визначивши ії споживачів у разі судового розгляду кримінальних справ - професійних представників сторін у суді [3, с. 8-9].

В.В. Конін також стверджує, що тактика як вид діяльності існує тільки там, де мають місце суперництво, протиборство, де стикаються інтереси груп, що суперечать один одному, а оскільки суд не має суперників, у нього не може бути й тактики [4]. Схожих поглядів дотримуються М.А. Погорецький та Д.Б. Сергєєва, котрі серед іншого звертають увагу на відсутність переконливих обгрунтувань протилежної точки зору, висловлюваної в роботах, автори яких не вбачають у спрямованості на подолання протидії визначальної ознаки криміналістичної тактики та вважають очевидним існування тактики під час провадження слідчих (розшукових) дій, де протидія відсутня [5].

Мета дослідження. Послідовно відстоюючи право суду на активну участь у процесі дослідження доказів, спробуємо усунути цю прогалину, маючи на меті поглиблення теоретичного обгрунтування необхідності розробки тактичних засобів оптимізації судової діяльності через системно-філософський аналіз відносин суду з іншими суб'єктами кримінального провадження.

Виклад основного матеріалу. У цілому доводи О.Я. Баєва та його однодумців можна звести до такого. Криміналістична тактика існує тільки в конфліктних умовах протиборства сил з різними цілями, а отже, вона не властива діяльності судді. Однак виключення суду з числа суб'єктів криміналістичної тактики, засноване на такому однобічному розумінні їі сутності, видається неприпустимим. Не можна зводити тактику тільки до тих прийомів і рекомендацій, які спрямовані на подолання протидії, опору зацікавленої сторони (підозрюваний, обвинувачений, лжесвідок тощо). Тактичні прийоми можуть бути спрямовані на подолання добросовісної помилки, на розширення й поглиблення дослідження у справі [6, с. 228]. На обгрунтування цього твердження наведемо такі міркування.

Стосовно конфліктності. Вважається, що кримінальне судочинство конфліктне за своєю природою [7, с. 155], адже в основі кожного злочину лежить конфлікт правопорушника із законом, з інтересами суспільства і держави [8, с. 153]. Будучи похідним від конфлікту кримінального, процесуальний конфлікт, на думку М.Ю. Лебедєва, є нормальним 
і неминучим проявом правових зв'язків і відносин між учасниками кримінально-процесуальної діяльності, котрі переслідують різні, частіше за все несумісні цілі, протягом як окремих етапів розслідування, так і всього ходу провадження у кримінальній справі [9].

Проте беззастережно погодитися з таким уявленням про зміст відносин, що виникають між суб'єктами кримінального процесу, не можна. Конфлікти в кримінальному провадженні справді можливі, але аж ніяк не «неминучі» й тим паче не «нормальні». Основою кожного конфлікту є протиріччя. Однак далеко не кожне протиріччя стає конфліктом. Протиріччя значно глибше, ніж конфлікт, що зумовлює необхідність філософського підходу до розуміння його сутності як центрального елемента закону єдності та боротьби протилежностей.

3 позиції діалектики (як методологічної основи вивчення будь-яких явищ дійсності) єдність завжди відносна, тоді як боротьба абсолютна, вона властива всім системам живої й неживої природи. Форми боротьби різноманітні й різнопланові. Як зазначає А.М. Авер'янов, битва, змагання, конкуренція, відштовхування, протидія та ін. - все це боротьба, але боротьба, яка має різні наслідки, яка призводить до різних результатів. Разом з тим на філософському рівні узагальнення всі ці явища визначаються як боротьба [10, с. 124-125]. Відтак уявлення про боротьбу тільки як про жорстке протистояння непримиренних сторін є надто спрощеним і таким, що збіднює методологічний потенціал діалектичного підходу до розуміння боротьби та іiі значення в розвитку буття, мислення й пізнання.

Протилежності, звичайно, протистоять одна одній, що, як правило, призводить до різноспрямованого характеру їх діяльності. Проте, якби взаємини між протилежностями зводилися тільки до протистояння, то ні про який розвиток систем не могло би бути й мови, що немислимо 3 діалектичної точки зору. Прояв сутності взаємодії протилежностей набагато різноманітніший. Протилежності, часто перебуваючи в системах різного порядку, в процесі взаємодії утворюють деяку динамічну структуру, самі при цьому залишаючись системними утвореннями 3 властивими кожній системі внутрішніми та зовнішніми протиріччями.

Протиріччя існують не тільки між окремими сутностями, але й між протилежними сторонами однієї сутності. Людина як жива, відкрита, складна система, активно взаємодіючи 3 навколишнім інформаційним середовищем, щось пізнає й запам'ятовує, але щось неминуче забуває. За потреби відтворення колись сприйнятого усвідомлення факту його забування викликає у людини негативні емоції, породжуючи внутрішнє протиріччя, яке виходить за межі особистості й стає зовнішнім, коли забування як параметр, що характеризує стан однієї системи, перешкоджає функціонуванню іншої системи в процесі їхньої взаємодії.

Добросовісний свідок, який прагне сприяти своїми показаннями з'ясуванню певних подій, ототожнюється метою з судом, для якого ці свідчення необхідні, щоб здійснити свою процесуальну функцію - ухвалити правильне рішення у справi. Незважаючи на це, між ними, як двома протилежностями єдиної системи під назвою «допит», може виникнути протиріччя внаслідок забування свідком обставин, які в момент ï сприйняття здавалися йому несуттєвими, але виявилися важливими для встановлення істини в кримінальному провадженні. Ця боротьба між бажанням і можливістю згадати забуте вимагає особливих методів, спрямованих на його актуалізацію. Як відзначають психологи, «відсутність відтворення лише свідчить про недоступність матеріалу на момент його запиту» [11]. Одного разу сприйнята інформація не зникає безслідно, але стає більш важкодоступною і вимагає спеціальних прийомів активації пам' яті, розробка яких відноситься до предметного поля криміналістичної тактики, що інтегрує необхідні для цього знання з галузі психології людини. Кожен суддя має досконало володіти цими прийомами і тактично грамотно їх застосовувати.

Для усвідомлення ролі суду та правильного розуміння факторів, які впливають на формування тактичних завдань, що постають у зв'язку з необхідністю отримання відомостей, які мають значення для правильного вирішення справи, важливо з'ясувати міжелементні зв'язки системи судового провадження, яке характеризується наявністю більшого (порівняно з досудовим розслідуванням) кола осіб, що беруть участь у розгляді справи і виконують кожен свою процесуальну функцію, стикаючись при цьому з різноманітними протиріччями. Найбільш типовим у системі «кримінальне провадження» є протиріччя між сторонами, котрі, слід зазначити, так само, як правило, утворюють системи, що складаються з декількох суб'єктів, які своєю чергою можуть розглядатися як системи «... в усьому багатстві їх змісту і з усіма їхніми індивідуальними якісними особливостями» [10, с. 134]. Нерідко можна також спостерігати протиріччя між представниками однієї сторони, між окремими представниками різних сторін, між сторонами (стороною або одним з ії представників) і судом. Можливі й цілком допустимі протиріччя між членами колегії суддів як 3 питань прийняття процедурних рішень, так і в оцінці доведеності фактичних обставин або їх правової кваліфікації.

Окрема процесуальна дія з ії неповторним складом учасників, кожен з яких має власні цілі, ціннісні орієнтири, поведінкові особливості, також часто демонструє наявність всіляких протиріч. У системі судового допиту, наприклад, взаємодіють кілька елементів (суб'єктів), цілі яких не завжди збігаються, відповідно, й відносини всередині цієї системи носять різний характер: хтось має на меті отримання від допитуваного достовірних відомостей про відомі йому обставини та всіляко цьому сприяє, хтось, навпаки, не бажає розкриття справжніх обставин справи і прагне цьому перешкодити, намагаючись заплутати, спантеличити допитувану особу, викликати у неї розгубленість, змусити втратити послідовність думки, спонукати до оціночних суджень щодо певних подій і одночасно посіяти внутрішній сумнів у правильності їх сприйняття та продемонструвати невпевненість допитуваного з метою дискредитації його показань.

Регулятивна роль суду в цьому хитросплетінні зв'язків і відносин з неминучістю передбачає наявність тих чи інших протиріч як неодмінного складника будь-якої взаємодії. Суддя має навчитися виявляти, адекватно оцінювати та вміло управляти протиріччями, спрямовуючи їх у конструктивне русло. Передбачення характеру розвитку ситуації та обрання відповідної тактики дає змогу суду найбільш ефективно впливати на сторони, не доводячи протиріччя до крайнього стану, який перешкоджає просуванню процесу до мети судового пізнання - встановлення істини у справі. Водночас слід пам'ятати, що суб'єктивне втручання суду в природний хід змагання сторін допустиме лише настільки, наскільки це необхідно для виключення подібного роду крайнощів. 
Стосовно протидії сил, які мають різні иілі. Слід нагадати, що криміналістична тактика в процесі їі становлення не пов' язувалася $з$ протидією певним силам. Так, наприклад, автори одного з перших вітчизняних підручників 3 криміналістики поряд із терміном «кримінальна тактика» використовували новий для того часу термін - «тактика розслідування злочинів», що розглядалася як «система прийомів досудового слідства, які дають можливість на основі вивчення особливостей кожної конкретної слідчої справи найбільш ефективно і 3 найменшою витратою сил та засобів реалізувати в цій справі вимоги кримінального матеріального й процесуального права» [12, с. 4-5].

На відміну від окремих криміналістів, які безумовною детермінантою застосування тактики вважають конфлікт взаємодіючих сторін, фахівці інших галузей знання, здається, не переймаються застосуванням терміна «тактика» щодо тих видів діяльності, які ще більш віддалені від умов конфліктності, аніж діяльність судова. Добре відома, скажімо, тактика лікування або тактика пожежогасіння. Пожежники протистоять вогневій стихії, медики - хворобі. При цьому боротьба за майно чи здоров'я та життя людей, не маючи в своїй основі міжособистісних конфліктів, стає ефективною лише за умови їі тактично грамотної організації. Так само й суд, не маючи особистих супротивників, щоразу бореться за встановлення істини й торжество справедливості, за особистість правопорушника, за те, щоб по можливості повернути суспільству гідного громадянина, аби покарання не стало тільки карою чи (що ще гірше) лише помстою або ізоляцією від соціуму. І для цього також необхідна спеціальна тактика.

Стосовно подолання перешкод. Перешкодами на шляху пізнання істини в кримінальному процесі можуть бути не тільки протидія зацікавлених осіб та конфлікти, але й психологічні особливості учасників судового розгляду, їхні взаємини, недостатня активність однієї зі сторін, помилки й прогалини досудового слідства тощо. Навіть загальні положення та принципи судового розгляду, які ставлять суддю й усіх учасників судового провадження в певні рамки і змушують їх діяти у відповідних умовах, можна розцінити як деяку перешкоду, оскільки не всі засоби й методи досягнення істини при цьому доступні. Суд має обрати такий тактично правильний хід судового розгляду, щоб усі ці перешкоди були успішно подолані.

Проводячи судові дії за клопотанням сторін або за власною ініціативою, суд має створити сторонам умови для реалізації ïx тактичного арсеналу i водночас не допустити порушення принципу рівноправності та змагальності сторін. Щоб правильно організувати й успішно провести судовий розгляд, не допустивши при цьому обвинувального ухилу і необгрунтованого потурання доводам захисту, потрібен не просто професіоналізм, а найвища майстерність, яка не приходить сама собою, а викристалізовується у головуючих суддів роками на основі підбору, розробки, застосування конкретних методичних рекомендацій $[13$, с. 66], в яких втілюються загальні основи аналізу судом криміналістичних ситуацій, прийняття тактичних рішень та способів їх реалізації.

Діяльність суду щодо здійснення доказування не порушує принципу змагальності, не доводить ні вину, ні невинність обвинуваченого. Діяльність суду в отриманні, перевірці та оцінці доказів у рамках судового розгляду необхідна для винесення справедливого й обгрунтованого вироку [14, с. 47], що може вважатися таким тільки за умови відповідності висновків суду справжнім обставинам справи, встановлення яких неможливе без залучення криміналістичних знань (зокрема, тактичних).

У змагальному кримінальному процесі суд має зберігати провідну роль у дослідженні доказів, інакше він перетвориться на орган, що формально оцінює зусилля сторін: перемагати в суді буде не справедливість, а той, хто виявився спритніший, хитріший у використанні матеріалів кримінальної справи, а змагальність 3 гарантії встановлення істини може перетворитися на формальну перешкоду успішному доказуванню в судовому розгляді [15, с. 244]. Тому слід підтримати позицію тих криміналістів, котрі вважають, що розширення змагальних засад кримінального судочинства не знімає з порядку денного розвитку науки криміналістики в напрямі розробки відповідних рекомендацій для стадії судового розгляду, а навпаки, вважають перспективною й актуальною розробку тактики ведення судового провадження [16, с. 19].

Висновки. Підсумовуючи, ще раз підкреслимо, що протиріччя, які лежать в основі боротьби протилежностей, $€$ невід'ємною частиною будь-якої форми взаємодії. Немає єдності без протиріччя, а отже, будь-яка взаємодія передбачає наявність боротьби, форма, динаміка та інтенсивність якої визначається специфікою об'єкта і характером відносин між взаємодіючими суб' єктами. Говорячи у зв'язку з цим про цільову спрямованість діяльності суб'єктів криміналістичної тактики, передусім, очевидно, слід вести мову не стільки про конфлікт, протиборство та подолання спротиву, скільки про усунення протиріч, що неминуче виникають під час реалізації учасниками кримінального провадження (зокрема, судом) своїх процесуальних функцій.

I наостанок зауважимо, що термін «тактика», запозичений 3 галузі військової науки, набув у криміналістиці іншого лексичного значення. А суть переносного значення слова, як відомо, полягає в тому, що воно пов'язує два різні за змістом поняття лише загальними точками дотику. Щодо тактики, яка наразі присутня в різних сферах людської діяльності, такою точкою слід вважати те загальне, що притаманне розумінню всякого виду тактичної діяльності як сукупності засобів і прийомів здійснення намічених цілей. Ця ознака через свою всезагальність стає домінуючою у формуванні поняття «тактика», відсуваючи на другий план конфліктність, наявність якої не має принципово детермінуючого значення.

\section{Jimepamypa:}

1. Лившиц Е.М., Белкин Р.С. Тактика следственных действий. М., 1997. $176 \mathrm{c}$.

2. Див., наприклад: Балашов Д.Н., Балашов Н.М., Маликов С.В. Криминалистика: учебник. М., 2005. 503 с.; Кофанов А.В., Кобилянський О.Л., Кузьмічов Я.В. та ін. Криміналістика: питання і відповіді: навч. посіб. К., 2011. 280 с.; Ларкін М.О., Сабадаш В.П. Криміналістика: навч. посіб. К., 2013. 228 с.; Пясковський В.В., Чорноус Ю.М., Іщенко А.В., Алєксєєв О.О. та ін. Криміналістика: підручник. К., 2015. 544 с.

3. Баев О.Я. Тактика уголовного преследования и профессиональной защиты от него. Следственная тактика: научно-практическое пособие. М., 2003. 432 с.

4. Конин В.В. Тактика и истина в судебном разбирательстве. Воронежские криминалистические чтения. Выпуск 6. Воронеж, 2005. C. $108-112$.

5. Погорецький М.А., Сергєєва Д.Б. Тактика захисника: поняття, зміст, та місце в системі криміналістичної тактики. Вісник кримінального судочинства. 2016. № 2. С. 113-123. 
6. Криминалистика: учебник для вузов / И.Ф. Герасимов, Я.Л. Драпкин, Е.П. Ищенко и др.; под ред. И.Ф. Герасимова, Л.Я. Драпкина. Москва, 2000. 672 с.

7. Астафьев А.Ю. Этико-правовые аспекты взаимодействия председательствующего судьи с участниками уголовного процесса. Судебная власть и уголовный процесс. 2015. № 4. С. 151-155.

8. Белкин Р.С. 2001. Курс криминалистики: учебное пособие для вузов: в 3 т. T. 1. Москва, URL: http://crimlib.info/images/a/af

9. Лебедев Н.Ю. К вопросу о понятии уголовно-процессуальных конфликтов. Известия Алтайского гос. ун-та. 2009. №. 2. С. 92-94.

10. Аверьянов А.Н. Системное познание мира: методологические проблемы. М., 1985. 263 с.

11. Нуркова В.В., Гофман А.А. Забывание: проблема наличия следа памяти, его доступности и намеренного контроля. Национальный психологический журнал. 2016. № 3(23). С. 64-71.

12. Криминалистика: учебник / под. ред. А.Я. Вышинского. М., 1938. $292 \mathrm{c}$

13. Гавло В.К., Жегалов Е.А. Тактика и методика судебного следствия. Юриспруденция. 2004. № 2. С. 64-71.

14. Цурлуй О.Ю. Субъекты криминалистической тактики. Проблемы правоохранительной деятельности. 2015. № 2. С. 43-48.

15. Кокорев Л.Д., Кузнецов Н.П. Уголовный процесс: доказательства и доказывание. Воронеж, 1995. 272 с.

16. Ищенко Е.П., Топорков А.А. Криминалистика: учебник. М., $2010.784 \mathrm{c}$.

Мирошниченко Ю. М. О детерминантах тактики суда в уголовном производстве

Аннотация. На основании системно-философского анализа отношений суда с другими субъектами уголовного производства обосновывается необходимость разработки тактических средств оптимизации судебной деятельности. Подчеркивается, что термин «тактика», заимствованный из области военной науки, приобрел в криминалистике иное лексическое значение. Сделан вывод о том, что определяющим для формирования понятия «тактика» является совокупность средств и прийомов достижения намеченных целей. В силу своей всеобщности этот признак становится доминирующим, отодвигая на второй план конфликтность, наличие которой в настоящее время не имеет принципиально детерминирующего значения.

Ключевые слова: уголовное производство, процессуальный конфликт, тактика суда.

Miroshnichenko Yu. About determinants of the tactics of the court in criminal proceedings

Summary. On the basis of a systematic and philosophical analysis of the relationship of the court with other subjects of criminal proceedings, the need to develop tactical means of optimizing judicial activity is substantiated. It is emphasized that the term "tactics", borrowed from the field of military science, has acquired a different lexical meaning in criminalistics science. The conclusion is made that the set of means and ways to achieve the intended goals is decisive for the formation of the concept of tactics. By virtue of its universality, this feature becomes dominant, overshadowing conflict, the presence of which currently has no fundamentally determining significance.

Key words: criminal proceedings, procedural conflict, court tactics. 